\title{
Quem tem medo da bancada evangélica? \\ Posições sobre moralidade e política no eleitorado brasileiro, no Congresso Nacional e na Frente Parlamentar Evangélica
}

Reginaldo Prandi e Renan William dos Santos

\begin{abstract}
Se há uma verdade que a história pôs fora de dúvida é a de que a religião engloba uma porção cada vez menor da vida social. Originalmente, ela se estende a tudo; tudo o que é social é religioso, as duas palavras são sinônimas. Depois, pouco a pouco, as funções políticas, econômicas e científicas se emancipam da função religiosa, constituem-se à parte e adquirem um caráter temporal cada vez mais acentuado. Deus, se é que podemos nos exprimir assim, que antes estava presente em todas as relações humanas, retira-se progressivamente delas; ele abandona o mundo aos homens e a suas disputas. Émile durkheim, Da divisão do trabalho social (2008, pp. 151-152).
\end{abstract}

Muito se tem dito sobre uma suposta influência crescente das religiões na política brasileira contemporânea. O principal sujeito dessa empreitada tem nome: a bancada evangélica. Trata-se de um grupo suprapartidário, composto por congressistas ligados a diferentes igrejas evangélicas, tanto do ramo histórico ou de missão como do pentecostal e neopentecostal, que atuariam em conjunto para aprovar ou rejeitar a legislação de interesse religioso e pautar diversas discussões no parlamento brasileiro. Seu nome oficial é Frente Parlamentar Evangélica, mas essa frente é correntemente chamada de bancada evangélica pela mídia, pela literatura científica, pelo Departamento Intersindical de Assessoria Parlamentar (Diap) e por seus próprios membros.

A bancada evangélica surgiu com a eleição da Assembleia Constituinte, no final de 1986, já com uma característica bem marcada e que permanece até hoje: não é política nem ideologicamente homogênea, mas é, de forma geral, conservadora. Esse ativismo conservador evangélico traz para a luta política demandas moralistas que são reivindicações reais dos setores populares, não habituados a separar as esferas da política e da moralidade privada (Pierucci, 1996a, pp. 165-166). Pouco afeitos à vida 
político-partidária do país durante décadas, os evangélicos entraram abertamente na disputa eleitoral temerosos de que a Constituição devolvesse à Igreja católica antigos e exclusivos privilégios. Temiam também que a nova carta incluísse a defesa dos homossexuais, dos comunistas, das feministas, da liberalização do aborto, do uso de drogas e de outros temas contrários à moral pregada por suas igrejas (Idem, p. 175; Prandi e Santos, 2015, p. 372).

De lá para cá, essa participação só fez crescer, ainda que algumas igrejas tenham permanecido alheias à política partidária, enquanto outras não somente se fizeram presentes em diferentes partidos como fundaram partidos próprios. Fim de uma era, na qual era lugar-comum dizer que crente não se metia em política - seja como crítica, feita pelos católicos, seja como autodefinição dos próprios evangélicos, pelo menos de boa parte deles (Pierucci, 1996a, p. 163).

Para a legislatura de 2015-2019 foram eleitos 75 deputados federais e três senadores publicamente identificados como evangélicos. Reunidos na bancada evangélica ${ }^{1}$, costumam votar coesos quando se trata de certas questóes morais lastreadas por interesse religioso comum. À bancada evangélica pode se juntar a escassa parcela de congressistas católicos interessados também em defender pontos de vista de sua religião, formando a chamada bancada da Bíblia, esse estranho conjunto composto por grupos historicamente em pé de guerra entre si.

Acontece que algo costuma ficar de fora da maioria das análises que alardeiam a atuação desses religiosos na política: a qualificação dos temas nos quais eles se engajam. Como se pretende demonstrar aqui, não se trata de "participação política" sem mais, e isso tem implicações teóricas extremamente relevantes.

Começando pelos eleitores, adiante será visto como os brasileiros assumem ou não posições diferentes conforme sua filiação religiosa ao opinar sobre temas ligados ao comportamento dos indivíduos è moral que os orienta, ou sobre questões relativas ao funcionamento da sociedade, do Estado e do governo. Diferentes religióes podem divergir sobre tudo isso. Trata-se de mostrar, sobretudo, que a religião de hoje dá tratamento privilegiado às coisas da intimidade em detrimento das coisas do governo da nação: o indivíduo é que ocupa o centro de sua preocupação.

Em um segundo momento serão comparadas as opiniões do eleitorado sobre os temas comportamentais e estruturais com as opiniões dos congressistas a respeito dos mesmos assuntos, especificando-se na comparação os parlamentares que compõem a chamada bancada evangélica. Com isso é possível comprovar em que

1. Entre outros dados, informações sobre o partido político, unidade da federação representada, profissão e igreja evangélica de cada um dos deputados que formam a bancada evangélica estão disponíveis em Diap (2014, pp. 106-109). 
direções as identidades e as posições religiosas influem ou não quando se entra no jogo político partidário.

O presente artigo se vale principalmente dos dados de duas pesquisas do Instituto Datafolha ${ }^{2}$, uma realizada em outubro de 2015, com uma amostra estatisticamente representativa de 340 parlamentares, e outra realizada em setembro de 2014, um levantamento de âmbito nacional, com uma amostra de 10054 eleitores. Em ambas, colhemos opiniões a respeito de temas como pena de morte, pobreza, maioridade penal, posse de armas, questões econômicas, benefícios de programas governamentais etc. A cada pesquisado foi apresentada uma bateria composta de pares de afirmações opostas, solicitando-se que o entrevistado escolhesse aquela com a qual concordava mais ${ }^{3}$. Em cada par é possível identificar uma afirmação mais conservadora e outra mais liberal, conforme concepção usual desses termos.

2. Os autores agradecem ao Datafolha e seu diretor-geral Mauro Paulino pelo tratamento e disponibilidade dos dados que possibilitaram a confecção deste trabalho.

3. Os pares de afirmações seguintes foram apresentados, nesta ordem, ao entrevistado, que deveria escolher, em cada par, a alternativa com a qual concordava mais, admitindo-se em cada item a resposta "não sei”: (a) Possuir uma arma legalizada deveria ser um direito do cidadão para se defender [ou] A posse de armas deve ser proibida, pois representa ameaça à vida de outras pessoas. (b) Boa parte da pobreza está ligada à preguiça de pessoas que não querem trabalhar [ou] Boa parte da pobreza está ligada à falta de oportunidades iguais para que todos possam subir na vida. (c) Pessoas pobres de outros países e Estados que vêm trabalhar na sua cidade acabam criando problemas para a cidade [ou] Pessoas pobres de outros países e Estados que vêm trabalhar na sua cidade contribuem com o desenvolvimento e a cultura. (d) A maior causa da criminalidade é a falta de oportunidades iguais para todos [ou] A maior causa da criminalidade é a maldade das pessoas. (e) A pena de morte é a melhor punição para indivíduos que cometem crimes graves [ou] Não cabe à Justiça matar uma pessoa, mesmo que ela tenha cometido um crime grave. (f) $\mathrm{O}$ uso de drogas deve ser proibido porque toda a sociedade sofre com as consequências [ou] O uso de drogas não deve ser proibido, porque é o usuário que sofre com as consequências. (g) A homossexualidade deve ser aceita por toda a sociedade [ou] A homossexualidade deve ser desencorajada por toda a sociedade. (h) Acreditar em Deus torna as pessoas melhores [ou] Acreditar em Deus não necessariamente torna uma pessoa melhor. (i) Os sindicatos são importantes para defender os interesses dos trabalhadores [ou] Os sindicatos servem mais para fazer política do que defender os trabalhadores. (j) Adolescentes que cometem crimes devem ser reeducados [ou] Adolescentes que cometem crimes devem ser punidos como adultos. (k) É bom que o governo atue com força na economia para evitar abusos das empresas [ou] Quanto menos o governo atrapalhar a competição entre as empresas, melhor para todos. (l) É preferível pagar menos impostos ao governo e contratar serviços particulares de educação e saúde [ou] É preferível pagar mais impostos ao governo e receber serviços gratuitos de educação e saúde. (m) Quanto menos eu depender do governo, melhor estará minha vida [ou] Quanto mais benefícios do governo eu tiver, melhor estará minha vida. (n) O governo tem o dever de ajudar grandes empresas nacionais que corram o risco de ir à falência [ou] O governo não deve ajudar grandes empresas nacionais que corram o risco de ir à falência. (o) As leis trabalhistas no Brasil mais atrapalham o crescimento das empresas do que protegem os trabalhadores, por isso boa parte delas deveria ser eliminada [ou] As leis trabalhistas no Brasil mais protegem os trabalhadores do que atrapalham o crescimento das empresas, por isso boa parte delas deveria ter seus benefícios ampliados. (p) As empresas privadas devem ser as maiores responsáveis por investir no país e fazer a economia crescer [ou] O governo deve ser o maior responsável por investir no país e fazer a economia crescer. 
Os dados básicos dessas duas pesquisas foram publicados no jornal Folha de $S$. Paulo na matéria "Parlamentares são mais liberais do que o eleitorado" (13/10/2015, p. A7). Posteriormente, os parlamentares da amostra foram separados em dois grupos: os que participam da bancada evangélica e os demais. Essa nova variável foi a base para o artigo "A política evangélica: em que temas ela é mais conservadora”, publicado no caderno "Ilustríssima" do mesmo jornal (Prandi e Paulino, 2015).

Os dados apresentados parcialmente nessas publicações foram aqui retomados e retrabalhados com informações provenientes de outras pesquisas, oportunamente identificadas, conduzindo-se agora a análise com um interesse sociológico específico: entender o sentido da participação dos evangélicos na política nacional, mostrando as diferenças de posição quando se comparam os congressistas que se assumem como representantes de religióes evangélicas com aqueles que não se distinguem por uma marca de filiação religiosa. Para melhor explicar a especificidade das religiões evangélicas nesse contexto político, a análise também buscou comparar a posição assumida, sobre as mesmas questões, pelo conjunto da população eleitoral e, separadamente, pelos segmentos dos católicos, dos evangélicos, dos seguidores das religiões afro-brasileiras, os de outras religiões e o dos sem religião e ateus. A religião considerada aqui é sempre a declarada pelo entrevistado. No caso dos evangélicos, as amostras permitiram conhecer também diferenças entre os pentecostais e os não pentecostais, tanto no âmbito do eleitorado como no do Congresso Nacional.

A presente análise permite reafirmar a ideia de que a religião, no contexto ocidental moderno, perdeu significativamente a capacidade de estruturar a política e a sociedade, ainda que permaneça presente no plano das convicçóes dos indivíduos, lugar em que se tornou uma opinião entre outras. Por isso, mesmo com seu reingresso no espaço público por meio de indivíduos identificados como representantes de suas religiões ou por elas indicados, a religião dos dias de hoje não pode mais ser vista como "figura da organização pública" ou como um "princípio fundador" de toda a sociedade, muito menos como formadora da cultura da nação (Ferry e Gauchet, 2008, pp. 22-23, 41). Quanto ao temor a que o título deste artigo alude - temor ou deslumbramento, depende de que lado se olha -, desejamos que tal tipo de sentimento seja arrefecido com alguma informação que este trabalho possa produzir.

Trabalhando-se inicialmente com a amostra do eleitorado, os temas referentes à moral e aos comportamentos foram classificados segundo a ordem decrescente da 
porcentagem de casos que optaram pela frase que mais bem expressa uma posição conservadora sobre o tema referido ${ }^{4}$.

Conforme os dados da Tabela 1, a asserção que mais unifica tanto católicos $(88,1 \%)$ como evangélicos pentecostais $(91,5 \%)$ e não pentecostais $(90,0 \%)$ é a de que "acreditar em Deus torna as pessoas melhores". A mais conservadora das escolhas afirma, emblematicamente, a obrigatoriedade da crença em Deus para se estar entre as pessoas de bem. Não é de estranhar que, no Brasil, declarar não acreditar em Deus, ou vacilar na resposta, possa pesar negativamente em uma disputa eleitoral (Pierucci e Prandi, 1996, p. 211). Isso reflete o amplo preconceito, ainda muito forte e difundido no Brasil, acerca da moralidade dos ateus. Conforme pesquisa conduzida pela Fundação Perseu Abramo, 42\% dos brasileiros declaram ter algum tipo de aversão a ateus, o que os coloca em primeiro lugar na escala de rejeição, à frente dos usuários de droga (que ocupam o segundo lugar), homossexuais, travestis, ex-presidiários e outros grupos sociais marginalizados (Venturi, 2008). Ou seja, assumir-se como ateu, no Brasil, é assumir a identidade mais intolerável em nossa sociedade. Talvez isso seja um dos fatores que expliquem a alta taxa dos que no censo de 2010 se declararam “sem religião" ( $8 \%$ da população), ao invés de “ateus” (0,3\%).É socialmente aceitável não seguir nenhuma religião, desde que se acredite em Deus ou que não se manifeste a descrença publicamente.

O tema das drogas vem em segundo lugar no consenso nacional de rejeição. A ampla maioria da população $(81,9 \%)$ acredita que o uso de drogas deve ser proibido, pois dele advêm problemas que afetam toda a sociedade, não só o usuário. Os grupos religiosos não se afastam dessa tendência. Mais uma vez, isso se coaduna à já citada pesquisa da Fundação Perseu Abramo. Essa moralização do problema das drogas pode ser um dos empecilhos ao avanço de políticas que busquem enfrentá-lo como questão de saúde pública.

O terceiro tema formador de maiorias conservadoras entre o eleitorado é o da redução da maioridade penal. Nas diferentes religiões (excluídos os sem religião e ateus), as cifras ficam todas muito próximas da taxa geral da população: 75,8\% concordam que adolescentes criminosos devem ser punidos como adultos. Esse

4. Em diferentes tabelas apresentadas, o total de casos é um pouco menor que a soma dos casos de cada um dos grupos de religião considerados para efeito de análise. A diferença é devida aos casos em que a pergunta sobre religião não foi respondida, e por isso foram excluídos do presente estudo. Vale acrescentar que não se tratou separadamente das religiões demograficamente minoritárias em razão do esperado pequeno número com que foram representadas nas amostras. As pesquisas do Datafolha aqui analisadas são amostrais, estatisticamente representativas das populações enunciadas, com margens de erro de $2 \%$ (pesquisa com o eleitorado) e de 3\% (pesquisa com congressistas), e intervalo de confiança de 95\%, conforme metodologia desenvolvida por Reginaldo Prandi usada nos levantamentos por amostragem do Datafolha. 


\begin{tabular}{|c|c|c|c|c|c|c|c|}
\hline $\begin{array}{l}\text { POSIÇÃO DO PESQUISADO } \\
\text { Optaram pela afirmação abaixo em vez de } \\
\text { afirmação com sentido oposto }\end{array}$ & 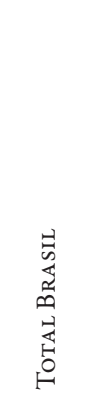 & 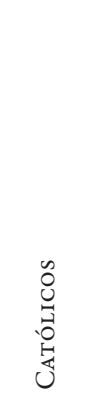 & 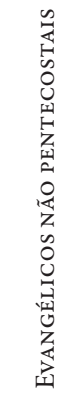 & 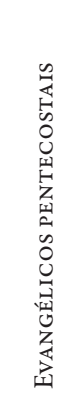 & 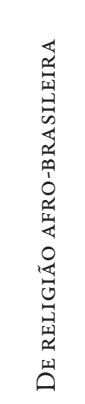 & 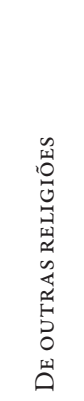 & 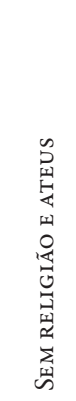 \\
\hline $\begin{array}{l}\text { Acreditar em Deus torna as pessoas } \\
\text { melhores }\end{array}$ & $85,6 \%$ & $88,1 \%$ & $90,0 \%$ & $91,5 \%$ & $63,6 \%$ & $65,6 \%$ & $17,3 \%$ \\
\hline $\begin{array}{l}\text { O uso de drogas deve ser proibido } \\
\text { porque toda a sociedade sofre com as } \\
\text { consequências }\end{array}$ & $81,9 \%$ & $83,3 \%$ & $83,8 \%$ & $85,1 \%$ & $74,3 \%$ & $77,8 \%$ & $51,5 \%$ \\
\hline $\begin{array}{l}\text { Adolescentes que cometem crimes devem } \\
\text { ser punidos como adultos }\end{array}$ & $75,8 \%$ & $77,3 \%$ & $76,6 \%$ & $74,3 \%$ & $70,8 \%$ & $73,3 \%$ & $53,7 \%$ \\
\hline $\begin{array}{l}\text { A maior causa da criminalidade é a mal- } \\
\text { dade das pessoas }\end{array}$ & $60,0 \%$ & $60,4 \%$ & $58,9 \%$ & $62,8 \%$ & $63,0 \%$ & $63,3 \%$ & $26,8 \%$ \\
\hline $\begin{array}{l}\text { A pena de morte é a melhor punição para } \\
\text { indivíduos que cometem crimes graves }\end{array}$ & $42,8 \%$ & $46,4 \%$ & $36,1 \%$ & $35,3 \%$ & $46,0 \%$ & $44,5 \%$ & $36,4 \%$ \\
\hline $\begin{array}{l}\text { Boa parte da pobreza está ligada à pregui- } \\
\text { ça de pessoas que não querem trabalhar }\end{array}$ & $37,6 \%$ & $38,9 \%$ & $35,9 \%$ & $36,8 \%$ & $37,0 \%$ & $43,3 \%$ & $17,9 \%$ \\
\hline $\begin{array}{l}\text { Possuir uma arma legalizada deveria ser } \\
\text { um direito do cidadão para se defender }\end{array}$ & $34,9 \%$ & $38,0 \%$ & $30,4 \%$ & $27,7 \%$ & $35,5 \%$ & $27,7 \%$ & $38,4 \%$ \\
\hline $\begin{array}{l}\text { A homossexualidade deve ser desencora- } \\
\text { jada por toda a sociedade }\end{array}$ & $27,4 \%$ & $21,5 \%$ & $40,3 \%$ & $44,9 \%$ & $9,2 \%$ & $8,4 \%$ & $21,1 \%$ \\
\hline $\begin{array}{l}\text { Pessoas pobres de outros países e estados } \\
\text { que vão trabalhar na sua cidade acabam } \\
\text { criando problemas para a cidade }\end{array}$ & $26,4 \%$ & $26,6 \%$ & $25,5 \%$ & $26,4 \%$ & $27,0 \%$ & $28,2 \%$ & $20,6 \%$ \\
\hline Número de casos & 10.054 & 5.880 & 2.057 & 610 & 184 & 143 & 816 \\
\hline
\end{tabular}

Fonte: Datafolha, pesquisa nacional realizada entre os dias 1 e 3 de setembro de 2014. 
tema relaciona-se com as opiniões acerca da causa da criminalidade. Para 60,0\% da população que vota, e novamente os diversos grupos de religiões acompanham essa cifra, as pessoas tornam-se criminosas não por causa da falta de oportunidades, mas porque são más. Crê-se que a criminalidade está na essência do indivíduo, não é algo ao qual ele é impelido por sua má inclusão na sociedade. Isso ajuda a entender a concepção de que um adolescente criminoso é um indivíduo mau como qualquer outro criminoso e por isso deve ser punido, não reeducado. $\mathrm{O}$ apoio à reeducação implica acreditar que novas oportunidades ajudam a escapar do mundo do crime. Se a criminalidade não se explica pela falta de oportunidades, mas pela maldade intrínseca, a reeducação passa a ser vista como esforço sem propósito.

A apologia à pena de morte para crimes graves é um divisor de águas. A partir dele, saímos dos temas em que a maioria assume uma posição mais conservadora. Aqui também começam a aparecer variações significativas entre os eleitores de diferentes religiões. Nesse quesito, os católicos que concordam com a pena de morte são 46,4\%, enquanto os evangélicos não pentecostais marcam 36,1\% e os pentecostais, 35,3\%. Foram exatamente os evangélicos, no período da Constituinte, o grupo social que mais se opôs à institucionalização da pena de morte no Brasil (Pierucci, 1996a, p. 175).

Vejamos como é avaliada pelos entrevistados a questão da pobreza. Em 37,6\% dos casos, o eleitorado brasileiro concorda que "boa parte da pobreza está ligada à preguiça de pessoas que não querem trabalhar": um bom contraponto às opinióes referentes à criminalização de adolescentes e pena de morte. Enquanto a falta de oportunidades naquele tema não era vista como um problema pela maioria, uma vez que a causa da criminalidade era a maldade, aqui as coisas se invertem: para a maioria da população e a de todos os grupos de religióes, a falta de oportunidades explica a condição de pobreza. Trata-se, portanto, de uma questão que não é mais moralizada - como já o foi em épocas em que a carteira de trabalho assinada era atestado de cidadania (W. Santos, 1979). Ser pobre não significa mais, para a opinião majoritária, ser vagabundo, preguiçoso, desleixado.

Segue-se a questão da legalização da posse de armas. Apenas uma minoria da população, nas diferentes religiões, acredita que a posse de armas deveria ser um direito do cidadão. Uma discrepância, entretanto, chama a atenção: enquanto os católicos aparecem com 38,0\% de aprovação do armamento pessoal, 3,1\% acima da média nacional (34,9\%), os evangélicos não pentecostais aparecem com 30,4\%, uma taxa $4,5 \%$ abaixo da nacional, e os pentecostais marcam apenas $27,7 \%$. Talvez essa baixa porcentagem entre os evangélicos pentecostais tenha a ver com o fato de que eles ainda têm sido recrutados, em sua maioria, entre os mais pobres da população brasileira (Pierucci e Prandi, 1996, p. 219; IBGE, 2012). Esse estrato social vive em contato mais direto com a criminalidade e a violência, principalmente nas favelas 
e nas periferias das grandes cidades, e pode, portanto, ter uma noção fundada no próprio cotidiano das consequências que o porte de arma traz a um contexto social.

O penúltimo item da Tabela 1 é o da rejeição à homossexualidade, pauta insistentemente propagandeada nos púlpitos e nas mídias por lideranças evangélicas de todo escalão, do pequeno pastor ou ancião aos populares pregadores notáveis e notórios. Enquanto no eleitorado como um todo apenas 27,4\% acham que "a homossexualidade deve ser desencorajada por toda sociedade", com uma rejeição ainda menor por parte dos católicos $(21,5 \%)$, entre os evangélicos essa taxa quase dobra: é de $40,3 \%$ entre os não pentecostais e de $44,9 \%$ entre os pentecostais. No grupo das outras religiões, a taxa é de mínimos 8,4\%, e entre os sem religião e ateus, $21,1 \%$.

A despeito do ativismo evangélico, a intolerância à homossexualidade vem declinando no Brasil. De fato, a insistência de congressistas evangélicos em tentar barrar o avanço dos direitos dos homossexuais pode resultar para a religião em um tiro no pé. Foi o que se viu com a atuação do Supremo Tribunal Federal, que instituiu no país o casamento de pessoas do mesmo sexo e estendeu aos gays outros direitos.

Dados do Pew Research Center (2013) sobre questões morais no Brasil também ajudam a ilustrar esse ponto. Conforme a Tabela 2, a intolerância à homossexualidade entre os brasileiros em geral aparece apenas em quinto lugar (39\%), atrás até mesmo do uso de álcool (47\%) e jogos de azar (64\%). É interessante notar que a rejeição ao sexo antes do casamento - outro tabu sexual tanto das religióes evangélicas como da católica - também aparece com uma taxa relativamente baixa (35\%). E os inexpressivos $8 \%$ de rejeição ao uso de contraceptivos são um bom indicador de uma certa liberalização do comportamento sexual.

TABELA 2

Opinião dos Brasileiros sobre se Cada Tema Apresentado é Moralmente Aceitável, Moralmente Inaceitável ou Não é uma Questão Moral

\begin{tabular}{|c|c|c|c|}
\hline TEMA & INACEITÁVEL & Aceitável & NÃO É UMA QUESTÃO MORAL \\
\hline Casos extraconjugais & $84 \%$ & $6 \%$ & $9 \%$ \\
\hline Aborto & $79 \%$ & $7 \%$ & $9 \%$ \\
\hline Jogos de azar & $64 \%$ & $15 \%$ & $19 \%$ \\
\hline Uso de álcool & $47 \%$ & $29 \%$ & $20 \%$ \\
\hline Homossexualidade & $39 \%$ & $44 \%$ & $14 \%$ \\
\hline Sexo antes do casamento & $35 \%$ & $47 \%$ & $14 \%$ \\
\hline Divórcio & $24 \%$ & $62 \%$ & $10 \%$ \\
\hline Uso de contraceptivos & $8 \%$ & $79 \%$ & $11 \%$ \\
\hline
\end{tabular}

Fonte: PEW (2013). Pesquisa com amostra de 960 brasileiros com dezoito anos ou mais, realizada em 2014. 
Os dados até aqui apresentados são corroborados e se completam pelos obtidos em uma outra investigação do Datafolha, realizada pouco antes da visita do Papa Francisco ao Brasil, em 2013. Ainda sobre a questão da homossexualidade, a Tabela 3 mostra que os grupos mais contrários à criminalização da homofobia são os evangélicos pentecostais, com 24,5\%, e os não pentecostais, com 21,2\%. A comparação da rejeição à criminalização entre os grupos religiosos mais uma vez demonstra que este é um tema que mobiliza os evangélicos de modo diferencial: apenas 15,9\% dos católicos, 10,6\% dos espíritas kardecistas e 9,6\% dos fiéis das religiões afro-brasileiras são contrários a essa pauta.

Quando se trata de rejeição à legalização do casamento entre pessoas do mesmo sexo e adoção de crianças por casais gays, os evangélicos não só disparam na comparação com as demais religiões como também formam a maioria dentro de seus grupos. Os pentecostais apresentam $63,3 \%$ e os não pentecostais $68,2 \%$ de rejeição ao casamento e $66,0 \%$ e 73,5\%, respectivamente, de rejeição à adoção. Cabe notar que, mesmo em se tratando da população em geral, esses temas geram uma maior rejeição do que aquela constatada na Tabela 1 . Embora somente $27,4 \%$ da população em geral opine que a homossexualidade deveria ser desencorajada, 43,3\% são contrários à legalização da união civil entre homossexuais e 48,5\% são contrários à adoção de crianças pelos casais gays.

Pesquisa do Datafolha realizada em 1997 mostrava uma rejeição maior: a porcentagem de reprovação à união homossexual era de 62\%, cifra à qual se contrapunham os $78 \%$ obtidos para os pentecostais e os $79 \%$ observados para os protestantes históricos (Mariano, 1999, p. 230, nota 8). Portanto, apesar do avanço observado, a aceitação da homossexualidade no Brasil tem seus limites. Os homossexuais podem ser (mais) aceitos, mas não com os mesmos direitos dos heterossexuais. Aceitação sim, pero no mucho. De todo modo, os números confirmam a rejeição à homossexualidade como assunto preferencial dos evangélicos, um dos pontos em torno do qual exercem maior pressão quando se trata de orientar as pessoas e estabelecer regras sobre os costumes.

Para completar o quadro de opiniões sobre comportamentos, temos, por fim, a questão referente aos migrantes e imigrantes. A Tabela 1 mostra que 26,4\% da população eleitoral brasileira acha que "pessoas pobres de outros países e estados que vão trabalhar na sua cidade acabam criando problemas para a cidade". Os grupos de religião acompanham essa taxa sem variações significativas. Não é de se estranhar a relativamente baixa rejeição aqui observada, uma vez que o Brasil é um país de imigrantes e migrantes internos, além de ter se transformado recentemente em um país também de emigração. Embora o preconceito contra nordestinos, por exemplo, ainda possa ser largamente observado, parte expressiva da população brasileira descende de 


\begin{tabular}{|c|c|c|c|c|c|c|c|}
\hline POSIÇÃO DO PESQUISADO & 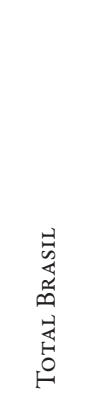 & 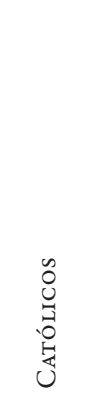 & 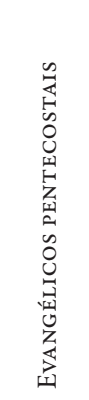 & 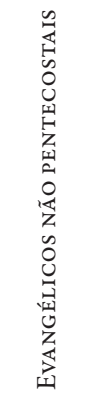 & 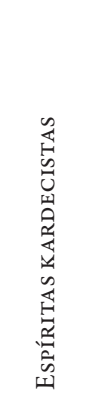 & 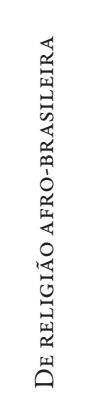 & 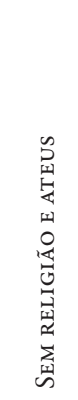 \\
\hline $\begin{array}{l}\text { Contrários à elaboração de uma lei } \\
\text { para punir quem intimidar, cons- } \\
\text { tranger ou ofender homossexuais }\end{array}$ & $18,1 \%$ & $15,9 \%$ & $24,5 \%$ & $21,2 \%$ & $10,6 \%$ & $9,6 \%$ & $19,0 \%$ \\
\hline $\begin{array}{l}\text { Contrários à legalização da união } \\
\text { entre pessoas do mesmo sexo }\end{array}$ & $43,3 \%$ & $36,1 \%$ & $63,3 \%$ & $68,2 \%$ & $20,9 \%$ & $15,3 \%$ & $29,3 \%$ \\
\hline $\begin{array}{l}\text { Contrários à adoção de crianças } \\
\text { por um casal gay }\end{array}$ & $48,5 \%$ & $42,2 \%$ & $66,0 \%$ & $73,5 \%$ & $32,2 \%$ & $22,6 \%$ & $33,2 \%$ \\
\hline $\begin{array}{l}\text { A mulher que interromper uma } \\
\text { gravidez deve ser processada e ir } \\
\text { para a cadeia }\end{array}$ & $63,9 \%$ & $64,7 \%$ & $71,6 \%$ & $64,6 \%$ & $40,2 \%$ & $50,4 \%$ & $50,2 \%$ \\
\hline Número de casos & 3.758 & 2.024 & 775 & 328 & 131 & 64 & 349 \\
\hline
\end{tabular}

Fonte: Datafolha, pesquisa nacional realizada de 6 a 7 de junho de 2013, com a população de 16 anos ou mais.

migrantes e imigrantes recentes ou tem na família pessoas que deixaram seu local de origem em busca de melhores condições de vida, o que pode mascarar o reconhecimento de um preconceito que é real e recorrente. Mas o que chama a atenção diante dos propósitos deste trabalho é que a filiação religiosa não interfere nesse quesito.

Saímos agora do plano da moral comportamental para adentrar no plano político-econômico. Aqui, conforme veremos, em praticamente nenhum dos temas a classificação por religião faz as opiniões dos eleitores variarem significativamente. $\mathrm{Ou}$ seja, os eleitores religiosos tendem a adotar as mesmas orientações difundidas na sociedade como um todo, orientações formadas a partir de influências outras que não as influências particulares a cada grupo de pertença religiosa. 
O primeiro item registrado na Tabela 4 é o da visão sobre os sindicatos. Aqui todas as categorias em análise parecem não tomar partido em relação à utilidade e à credibilidade dos sindicatos: uns pouco acima, outros pouco abaixo dos 50,0\%. A exceção se dá no grupo dos sem religião e ateus, no qual apenas 33,6\% têm uma visão mais negativa, que considera que "os sindicatos servem mais para fazer política do que defender os trabalhadores".

A distância entre a comunidade oriunda dos laços religiosos e a comunidade secular fundada em laços trabalhistas (sindicatos) foi superada, nos anos da ditadura brasileira, pelo movimento católico das Comunidades Eclesiais de Base, exatamente no momento em que a Igreja católica era praticamente o único ator social cuja voz se podia ouvir - e ela soube trabalhar muito bem, nesse período, sua imagem de representante do povo (Pierucci, 1996b). O sindicato, ao se aproximar da religião, falava através dela. Com a redemocratização, no entanto, o sindicato retornou ao seu lugar privilegiado de portador do discurso dos trabalhadores. O laço entre o sindicato e a igreja dissolveu-se, e a tensão entre grupos religiosos e outras organizações da sociedade civil reascendeu (Prandi e Souza, 1996).

O item sobre o pagamento de impostos em troca de serviços de educação e saúde também apresenta a mesma distribuição equânime relativa ao apoio ou à rejeição da interferência do governo no funcionamento da economia. Dessa vez, porém, nenhum grupo aparece significativamente destoante de todos os outros, nem os "sem religião", que marcam $47,4 \%$, enquanto a média geral é 49,3\%. Portanto, as religiões não influenciam, não direcionam nem condicionam a opinião dos entrevistados nesse tema socioeconômico vital ao funcionamento estrutural da sociedade.

A tendência mantém-se no item seguinte: as diferentes pertenças religiosas não fazem variar muito a aceitação da ideia de que "quanto menos eu depender do governo, melhor estará minha vida”, que registra, mais uma vez, basicamente a metade dos entrevistados: 48,6\%. Mas os sem religião e ateus destoam: 60,6\% consideram ruim a dependência de benefícios do governo. Pertencer a uma religião qualquer, portanto, tende a matizar um pouco a aversão à dependência do governo.

Nos próximos itens, entretanto, os brasileiros começam a tomar partido em oposição ao liberalismo econômico. Só 34,8\% do eleitorado acha que "quanto menos o governo atrapalhar a competição entre as empresas, melhor para todos”. A taxa pouco varia entre os grupos católicos e evangélicos, mas despenca entre os sem religião e ateus, com 19,4\% de aceitação da premissa liberal.

O fenômeno repete-se quase com as mesmas proporções no tema das leis trabalhistas. Do eleitorado, 33,0\% acham que as leis trabalhistas mais atrapalham as empresas do que ajudam os trabalhadores. Os grupos religiosos acompanham de perto essa taxa. Entre os sem religião e ateus, somente 17,8\% têm essa mesma visão. 
TABELA 4

Opinião dos Eleitores Brasileiros sobre as Questões Econômicas e Governamentais Enumeradas Segundo a Religião Declarada do Congressista

\begin{tabular}{|c|c|c|c|c|c|c|c|}
\hline POSIÇÃO DO PESQUISADO & 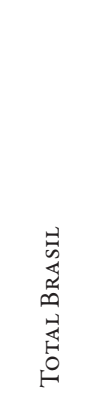 & $\begin{array}{l}0 \\
0 \\
0 \\
. \\
0 \\
0 \\
0 \\
0\end{array}$ & 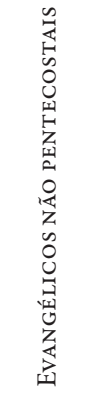 & 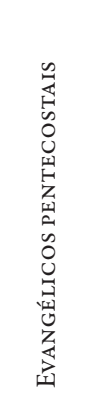 & 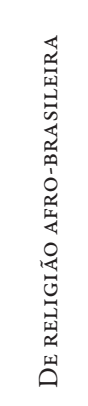 & 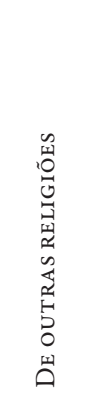 & 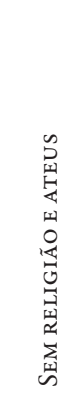 \\
\hline $\begin{array}{l}\text { Os sindicatos servem mais para fazer po- } \\
\text { lítica do que defender os trabalhadores }\end{array}$ & $49,5 \%$ & $47,8 \%$ & $52,2 \%$ & $48,7 \%$ & $57,6 \%$ & $59,5 \%$ & $33,6 \%$ \\
\hline $\begin{array}{l}\text { É preferível pagar menos impostos ao } \\
\text { governo e contratar serviços particulares } \\
\text { de educação e saúde }\end{array}$ & $49,3 \%$ & $49,2 \%$ & $55,3 \%$ & $47,6 \%$ & $43,5 \%$ & $45,8 \%$ & $47,4 \%$ \\
\hline $\begin{array}{l}\text { Quanto menos eu depender do governo, } \\
\text { melhor estará minha vida }\end{array}$ & $48,6 \%$ & $48,7 \%$ & $46,0 \%$ & $45,0 \%$ & $54,7 \%$ & $54,5 \%$ & $60,6 \%$ \\
\hline $\begin{array}{l}\text { Quanto menos o governo atrapalhar a } \\
\text { competição entre as empresas, melhor } \\
\text { para todos }\end{array}$ & $34,8 \%$ & $34,4 \%$ & $37,8 \%$ & $33,7 \%$ & $43,1 \%$ & $41,8 \%$ & $19,4 \%$ \\
\hline $\begin{array}{l}\text { As leis trabalhistas no Brasil mais atrapa- } \\
\text { lham o crescimento das empresas do que } \\
\text { protegem os trabalhadores, por isso boa } \\
\text { parte delas deveria ser eliminada }\end{array}$ & $33,0 \%$ & $33,0 \%$ & $37,8 \%$ & $31,3 \%$ & $32,6 \%$ & $35,1 \%$ & $17,8 \%$ \\
\hline $\begin{array}{l}\text { O governo não deve ajudar grandes } \\
\text { empresas nacionais que corram o risco } \\
\text { de ir à falência }\end{array}$ & $30,2 \%$ & $30,9 \%$ & $27,9 \%$ & $24,3 \%$ & $45,1 \%$ & $42,7 \%$ & $45,1 \%$ \\
\hline $\begin{array}{l}\text { As empresas privadas devem ser as } \\
\text { maiores responsáveis por investir no país } \\
\text { e fazer a economia crescer }\end{array}$ & $22,5 \%$ & $22,5 \%$ & $19,0 \%$ & $21,0 \%$ & $24,5 \%$ & $26,8 \%$ & $29,9 \%$ \\
\hline Número de casos & 10.054 & 5.880 & 2.057 & 610 & 184 & 143 & 816 \\
\hline
\end{tabular}

Fonte: Datafolha, pesquisa nacional realizada entre os dias 1 e 3 de setembro de 2014. 
Mais uma vez, as diferentes religiões parecem não ter peso na formação desse tipo de opinião entre os eleitores. A única condição significativa é o fato mesmo de se ter alguma religião em vez de nenhuma.

As coisas mostram-se embaralhadas quando se trata de opinar se o governo deve ajudar as grandes empresas nacionais. Os católicos têm uma taxa de 30,9\% de rejeição, os evangélicos não pentecostais, 27,9\%, e os evangélicos pentecostais, $24,3 \%$. Os adeptos de outras religiões e os sem religião e ateus, por sua vez, dão um salto em direção ao liberalismo econômico, com taxas respectivas de 42,7\% e 45,1\% de rejeição à intervenção estatal. Mas a tendência retorna no último item, em que, entre todos, a população em geral se mostra menos liberal. Apenas 22,5\% acham que "as empresas privadas devem ser as maiores responsáveis por investir no país e fazer a economia crescer".

Como vimos, na maioria dos casos a pertença a um grupo religioso específico tende a não fazer diferença na distribuição das opiniões relativas aos diversos temas estruturais abordados. Em alguns itens, o fato de se ter alguma religião, em oposição a nenhuma, pode até ter um peso relativo. Mas é apenas quando se trata de "preservar a moralidade privada tradicional" que a atuação política religiosa é destacada (Pierucci, 1996a, pp. 178, 184), pois esse tipo de preocupação é transportado ao Congresso Nacional pelos representantes religiosos que, entretanto, nos temas alheios à moral e aos comportamentos, tendem a não se distinguir dos demais parlamentares, como veremos a seguir.

Depois dessa incursão pelas opiniões da população brasileira a respeito de questões de moralidade e comportamento, de um lado, e daquelas referidas à economia e atuação do governo, de outro, trata-se de ver agora como reagem os parlamentares, ou seja, os representantes desse povo, quando as mesmas proposições lhes são apresentadas.

$\mathrm{Na}$ Tabela 5 estão os dados referentes aos temas da moralidade e dos comportamentos e na Tabela 6, os dados sobre questões econômicas e governamentais. Os resultados estão disponíveis para três grupos: o conjunto dos congressistas, a bancada evangélica em seu conjunto (não pentecostais e pentecostais) e a parte pentecostal da bancada evangélica.

O primeiro item da Tabela 5 já mostra que aquele forte preconceito contra os ateus, presente no eleitorado brasileiro, nem de longe se reflete com a mesma força no Congresso. Apenas 67,3\% dos parlamentares concordam que acreditar em Deus torna as pessoas melhores. Mesmo os parlamentares pentecostais estão defasados 
neste quesito: $79,3 \%$ concordam, enquanto que entre os eleitores pentecostais a afirmação foi aceita por $91,5 \%$ dos entrevistados.

TABELA 5

Opinião dos Congressistas Brasileiros sobre as Questöes Morais e de Comportamento Enumeradas Segundo a Religião Declarada

\begin{tabular}{|c|c|c|c|}
\hline PoSIÇÃO DO PESQUISADO & 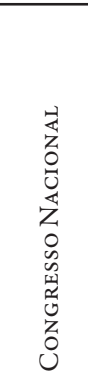 & 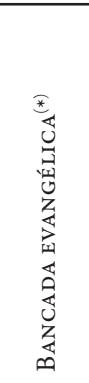 & 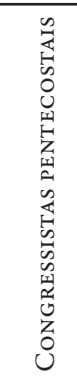 \\
\hline $\begin{array}{l}\text { Acreditar em Deus torna as pessoas } \\
\text { melhores }\end{array}$ & $67,3 \%$ & $85,9 \%$ & $79,3 \%$ \\
\hline $\begin{array}{l}\text { O uso de drogas deve ser proibido } \\
\text { porque toda a sociedade sofre com as } \\
\text { consequências }\end{array}$ & $78,3 \%$ & $95,3 \%$ & $97,2 \%$ \\
\hline $\begin{array}{l}\text { Adolescentes que cometem crimes } \\
\text { devem ser punidos como adultos }\end{array}$ & $38,2 \%$ & $38,5 \%$ & $46,6 \%$ \\
\hline $\begin{array}{l}\text { A maior causa da criminalidade é a } \\
\text { maldade das pessoas }\end{array}$ & $16,7 \%$ & $20,1 \%$ & $22,5 \%$ \\
\hline $\begin{array}{l}\text { A pena de morte é a melhor punição } \\
\text { para indivíduos que cometem crimes } \\
\text { graves }\end{array}$ & $8,1 \%$ & $9,6 \%$ & $0 \%$ \\
\hline $\begin{array}{l}\text { Boa parte da pobreza está ligada à } \\
\text { preguiça de pessoas que não querem } \\
\text { trabalhar }\end{array}$ & $6,3 \%$ & $9,3 \%$ & $5,3 \%$ \\
\hline $\begin{array}{l}\text { Possuir uma arma legalizada deveria ser } \\
\text { um direito do cidadão para se defender }\end{array}$ & $42,2 \%$ & $58,7 \%$ & $67,6 \%$ \\
\hline $\begin{array}{l}\text { A homossexualidade deve ser desenco- } \\
\text { rajada por toda a sociedade }\end{array}$ & $14,4 \%$ & $46,2 \%$ & $41,9 \%$ \\
\hline $\begin{array}{l}\text { Pessoas pobres de outros países e esta- } \\
\text { dos que vão trabalhar na sua cidade aca- } \\
\text { bam criando problemas para a cidade }\end{array}$ & $12,2 \%$ & $14,9 \%$ & $19,0 \%$ \\
\hline Número de casos & 340 & 40 & 33 \\
\hline
\end{tabular}

${ }^{(*)}$ Inclui congressistas evangélicos pentecostais e evangélicos não pentecostais.

Fonte: Datafolha, pesquisa realizada entre os dias 15 de setembro e 9 de outubro de 2015 com amostra de 340 parlamentares.

Sobre o tema das drogas, as coisas também se tornam um pouco mais complexas no âmbito do Congresso: enquanto a moralização do uso de drogas é semelhante comparando-se a população em geral $(81,9 \%)$ com o conjunto dos parlamentares (78,3\%), a comparação entre a rejeição por parte do eleitorado pentecostal (85,1\%) e a dos congressistas pentecostais $(97,2 \%)$ revela uma sobrevalorização parlamentar 
do tema, não só entre os parlamentares evangélicos, mas em toda a Casa (78,3\%). Também é o que mais aproxima pentecostais de não pentecostais no interior da bancada evangélica. Essa quase unanimidade não significa, porém, que esse seja o assunto de maior empenho por parte dos congressistas evangélicos.

O contrário acontece em relação ao tema da maioridade penal: só $38,2 \%$ dos parlamentares acham que a maioridade penal deveria ser reduzida para crimes violentos, um número que fica próximo apenas da metade do que consta entre o eleitorado geral (75,8\%). O mesmo acontece na comparação da bancada evangélica com a população evangélica: $38,5 \%$ de aceitação de redução da maioridade penal na bancada evangélica, contra $76,6 \%$ e 74,3\% entre a população evangélica não pentecostal e pentecostal, respectivamente. Aqui há uma subvalorização parlamentear do tema.

É de suma importância ao argumento que se está desenvolvendo aqui a constatação de que a posição da bancada evangélica no Congresso tem enorme independência e defasagem em relação às opiniões professadas pelos eleitores evangélicos, seja para cima, como já vimos no caso de uso de drogas, seja para baixo, como estamos vendo agora no tema da maioridade penal e também veremos a seguir em diversos outros temas.

O item seguinte é o da causa da criminalidade. De forma parelha com o Congresso como um todo (16,7\%), apenas $20,1 \%$ da bancada evangélica é da opinião de que "a maior causa da criminalidade é a maldade das pessoas". Ou seja, toda aquela concepção de que a maldade é intrínseca ao indivíduo e nada tem a ver com a falta de oportunidades - algo que, como vimos, é muito forte entre o eleitorado evangélico - é rechaçada pela ampla maioria dos parlamentares evangélicos. Isso fica ainda mais evidente no item seguinte: só 9,6\% da bancada evangélica é a favor da pena de morte, e, entre os congressistas pentecostais, não há sequer um que apoie a ideia. A discrepância em relação aos números do eleitorado evangélico é esmagadora, mesmo se levando em conta que os evangélicos são relativamente a parcela da população que menos apoia a pena de morte. Portanto, também nesses dois temas a bancada evangélica se mostra independente em relação às opiniões de seu eleitorado.

O mesmo se repete no item sobre a causa da pobreza. Só 9,3\% dos parlamentares da bancada evangélica acreditam que a pobreza deriva da preguiça das pessoas e não da falta de oportunidades, o que os coloca muito próximos da opinião geral do Congresso, que marca 6,3\% de aquiescência àquela afirmação. Tudo isso fica muito longe, mais uma vez, da opinião constatada tanto na sociedade em geral como nos diferentes grupos religiosos, conforme já se mostrou anteriormente. Como ocorre em temas já vistos, os políticos evangélicos tendem a pensar mais como políticos do que como evangélicos, acompanhando de perto a opinião geral do Congresso, muito mais do que expressando posições assumidas pelo eleitorado, religioso ou não religioso. 
Quanto à legalização da posse de armas, a aceitação do parlamento em geral é um pouco maior do que a da sociedade, $42,2 \%$ contra $34,9 \%$, respectivamente. Já a anuência da bancada evangélica em relação a esse tema é bem maior $(58,7 \%)$, e mais ainda quando se levam em conta apenas os congressistas pentecostais $(67,6 \%)$. É curioso que a maioria dos deputados evangélicos ache que a posse de armas deveria ser um direito do cidadão, enquanto a maioria do eleitorado evangélico acha que a posse de armas deveria ser proibida.

Com isso, chegamos ao mais controverso dos temas: o da homossexualidade. A mesma constatação verificada na população aparece potencializada entre os políticos: somente $14,4 \%$ dos congressistas têm uma visão negativa da homossexualidade, mas essa taxa sobe para 46,2\% na bancada evangélica. A diferença é gritante, muito maior do que aquela que se constata entre a rejeição do eleitorado em geral $(27,4 \%)$ comparada com a dos evangélicos não pentecostais (40,3\%) e a dos pentecostais $(44,9 \%)$. Esse é, portanto, o tema por excelência em torno do qual se mobilizam os eleitores e mais ainda os parlamentares evangélicos. Não por acaso, entre todos os temas abordados, é o que a bancada evangélica fica mais distante da posição dos parlamentares em geral e mais próxima de seus representados.

Cabe, porém, não superestimar o poder da bancada evangélica mesmo nesse tema. Como já dissemos anteriormente, a atuação desses parlamentares tende a ser eminentemente reacionária. Ou seja, é muito mais provável que eles atuem para se opor à criminalização da homofobia do que para propor a criminalização da homossexualidade, por exemplo. Seja na sociedade, seja no parlamento, a religião, evangélica ou não, quando procura se impor, age como um freio ao avanço da modernidade, não mais como ideologia orientadora da ação, como guia para todos, como "farol da política contemporânea” e da sociedade (Prandi e Santos, 2015, p. 373).

Resta ainda um tema que promete ocupar, em breve, também a cena brasileira, como ocorre hoje na Europa: a questão dos deslocamentos migratórios. Interessante que a população parece muito mais conservadora que o Congresso quando opina negativamente sobre o papel dos migrantes e imigrantes. De fato, os políticos apresentam porcentagens próximas à metade das observadas na população: $12,2 \%$ contra $26,4 \%$, respectivamente. Embora a taxa de rejeição varie pouco nos diferentes grupos religiosos na população, no Congresso são os pentecostais da bancada evangélica que apresentam o valor mais elevado: 19,0\% acham que pobres migrantes e imigrantes causam problemas às cidades que os recebem.

Em suma, os congressistas, assim como a bancada evangélica, são mais progressistas que o eleitorado ao endossar menos as ideias segundo as quais a pobreza tem como causa a preguiça, os migrantes são responsáveis por problemas sociais, a maldade da pessoa explica o crime e acreditar em Deus torna as pessoas melhores. 
No campo da sexualidade, porém, a bancada evangélica realmente se destaca como fração contrária à modernização dos costumes. Sem dúvida, parece ser essa a coroa que encima seu brasão moral, entre outras notórias rejeições antimodernas de caráter moralista. Mesmo com assento na mais importante assembleia do país, a maioria dos representantes evangélicos mantém seu foco nos costumes que a sociedade, cada vez mais, transforma em marcas do passado. Em outras pautas, porém, parece aprender com a Casa e seus partidos.

Como no plano das questões morais e comportamentais, também na maioria das questões do plano estrutural socioeconômico as opiniões dos congressistas evangélicos tendem a guardar pouca relação com as do eleitorado evangélico.

A Tabela 6 revela que a visão negativa em relação aos sindicatos é muito maior na bancada evangélica $(62,6 \%)$ e mais ainda entre os congressistas pentecostais $(68,0 \%)$ do que no Congresso em geral (41\%) e também do que entre qualquer dos grupos de religião do eleitorado. Para a maioria dos congressistas evangélicos, "os sindicatos servem mais para fazer política do que defender os trabalhadores". Essa visão negativa em relação aos sindicatos pode ter relação tanto com aquela experiência de proximidade que houve entre os sindicatos e as comunidades eclesiais de base católicas, quanto com a ligação simbólica entre sindicatos, a esquerda e o comunismo. Como sabemos, não só a ida dos evangélicos à política, escancarada na Constituinte, mas também seu apoio à candidatura presidencial de Fernando Collor tinham como objetivo principal a defesa da liberdade religiosa contra aquilo que consideravam uma dupla ameaça: a esquerda comunista e ateia e o catolicismo imperialista (Pierucci e Mariano, 1996).

O tema relativo à preferência por serviços públicos pagos com impostos, em detrimento de serviços particulares nas áreas da saúde e educação, registra variações pouco significativas das opinióes tanto no interior do eleitorado e do Congresso como na comparação entre os dois. As variações ficam próximas da casa dos 50\%.

Já os itens sobre dependência do governo, competição entre empresas e leis trabalhistas apontam em conjunto em uma mesma direção: em se tratando da esfera econômica, o Congresso é muito mais liberal do que a população em geral, e os evangélicos no Congresso o são ainda mais, seja na comparação com a população total, seja na comparação com os eleitores evangélicos.

A ideia de receber auxílios do governo é vista com maus olhos por $87,0 \%$ dos parlamentares da bancada evangélica, número muito maior que o da população em geral (48,6\%), ainda que não tão maior quando comparado ao Congresso como um 


\begin{tabular}{|c|c|c|c|}
\hline PoSIÇÃO DO PESQUISADO & 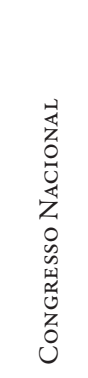 & 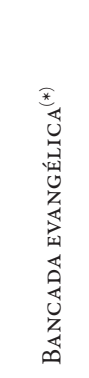 & 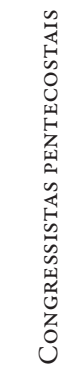 \\
\hline $\begin{array}{l}\text { Os sindicatos servem mais para fazer política } \\
\text { do que defender os trabalhadores }\end{array}$ & $41,0 \%$ & $62,6 \%$ & $68,0 \%$ \\
\hline $\begin{array}{l}\text { É preferível pagar menos impostos ao go- } \\
\text { verno e contratar serviços particulares de } \\
\text { educação e saúde }\end{array}$ & $40,0 \%$ & $47,6 \%$ & $52,8 \%$ \\
\hline $\begin{array}{l}\text { Quanto menos eu depender do governo, } \\
\text { melhor estará minha vida }\end{array}$ & $77,4 \%$ & $87,0 \%$ & $78,8 \%$ \\
\hline $\begin{array}{l}\text { Quanto menos o governo atrapalhar a com- } \\
\text { petição entre as empresas, melhor para todos }\end{array}$ & $64,5 \%$ & $85,3 \%$ & $69,8 \%$ \\
\hline $\begin{array}{l}\text { As leis trabalhistas no Brasil mais atrapalham } \\
\text { o crescimento das empresas do que protegem } \\
\text { os trabalhadores, por isso boa parte delas } \\
\text { deveria ser eliminada }\end{array}$ & $44,9 \%$ & $49,3 \%$ & $47,0 \%$ \\
\hline $\begin{array}{l}\text { O governo não deve ajudar grandes empresas } \\
\text { nacionais que corram o risco de ir à falência }\end{array}$ & $40,3 \%$ & $52,5 \%$ & $49,5 \%$ \\
\hline $\begin{array}{l}\text { As empresas privadas devem ser as maiores } \\
\text { responsáveis por investir no país e fazer a } \\
\text { economia crescer }\end{array}$ & $60,1 \%$ & $57,6 \%$ & $48,1 \%$ \\
\hline Número de casos & 340 & 40 & 33 \\
\hline
\end{tabular}

${ }^{(*)}$ Inclui congressistas evangélicos pentecostais e evangélicos não pentecostais.

Fonte: Datafolha, pesquisa realizada entre os dias 15 de setembro e 9 de outubro de 2015 com amostra de 340 parlamentares.

todo $(77,4 \%)$. No caso dos membros da bancada evangélica, essa aversão à dependência dos benefícios do governo pode estar ligada a uma ideologia de empreendedorismo do tipo self-made man em busca da prosperidade que permeia as pregações e as teologias das mais diversas igrejas evangélicas (Souza, 2011). Lembremos que essa ideologia deve aparecer maximizada no âmbito parlamentar por se tratar de um posto ao qual em geral apenas as lideranças evangélicas ascendem, justamente os líderes responsáveis por difundir tal ideologia entre os fiéis na prédica cotidiana. 
No item sobre a competição entre empresas, o liberalismo econômico do parlamento aparece com ainda menos enraizamento social. A taxa de parlamentares que concorda que "quanto menos o governo atrapalhar a competição entre as empresas, melhor para todos" é de $64,5 \%$, quase o dobro do constatado entre a população (34,8\%). E a discrepância cresce ainda mais considerando-se apenas a bancada evangélica, que marca 85,3\% de concordância com essa afirmação.

$\mathrm{Na}$ questão das leis trabalhistas, tanto para o Congresso em geral (44,9\%) como para a bancada evangélica (49,3\%), elas são vistas com mais desconfiança do que entre a população em geral (33,0\%). O mesmo acontece quando se trata do tema da intervenção do governo para ajudar empresas nacionais, ideia rechaçada por 40,3\% dos parlamentares em geral (um número um pouco maior que os 30,2\% presentes na população como um todo) e por $52,5 \%$ da bancada evangélica.

Por fim, 60,1\% do conjunto dos parlamentares e 57,6\% da bancada evangélica concordam que as empresas privadas devem ser as principais responsáveis pelo crescimento econômico do país, e não o governo. Um número esmagadoramente maior dos que os 22,5\% do eleitorado que compartilham dessa opinião.

Assim, se na esfera da sociedade brasileira como um todo a filiação religiosa tendia a não influir na opinião dos eleitores em temas econômicos e estruturais, pois os diferentes grupos religiosos concordavam com posições mais intervencionistas e protecionistas, no Congresso a filiação religiosa também tem pouca importância nesses temas, pois os parlamentares, independentemente de sua religião, inclinam-se mais para o liberalismo econômico - lado oposto daquele dos eleitores.

Isso tudo quer dizer que a pertença religiosa é pouco relevante na formação de opiniões em relação a temas econômicos e estruturais que dizem respeito ao funcionamento das instituições vitais do país. Isso vale para dentro e para fora do Congresso Nacional. Nesses temas, a religião não tem o que dizer. Importam muito mais as orientações que o parlamentar recebe de outros campos e atores: o partido político, a origem socioeconômica, a formação escolar etc.

Vimos que a pertença religiosa, no eleitorado total, tende a ter peso significativo na formação da opinião a respeito de assuntos referentes à moral e aos comportamentos, mas pouco interfere quando se trata de questões mais estruturais. Vimos ainda que, ao passar para o universo dos políticos, esse peso da filiação religiosa tende a diminuir, e as opiniões da bancada evangélica são mais atenuadas mesmo em questões morais e comportamentais, exceto quando se trata da moral sexual. A bancada evangélica é conservadora como a maioria dos eleitores quando o assunto é comportamento. É 
conservadora também, mas agora na companhia dos seus pares no Congresso, quando se trata de questões da economia e do governo. Muda de parceiros conforme olha ou para o indivíduo e sua intimidade ou para a o Estado e seus problemas econômicos. Mas não muda de gosto.

Veremos agora se os fiéis valorizam a presença de seus representantes religiosos no Congresso. A Tabela 7 mostra que, em geral, apenas uma pequena parcela dos eleitores de qualquer filiação religiosa diz levar em conta as instruções de líderes religiosos que fazem campanha para políticos ligados à igreja. Entretanto, apesar de minoritária, a parcela dos evangélicos pentecostais é relativamente grande (20,7\%) na comparação com os demais grupos religiosos - os católicos, por exemplo, aparecem com 10,9\%.

\begin{tabular}{|c|c|c|c|c|c|c|c|}
\hline Questão & 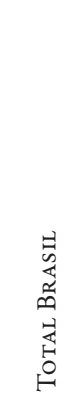 & 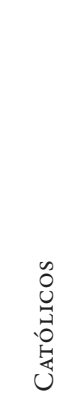 & 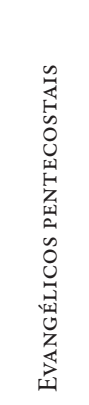 & 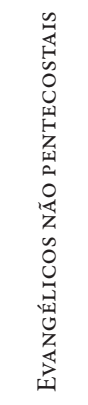 & 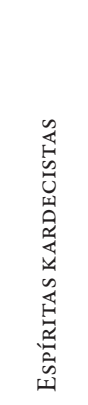 & 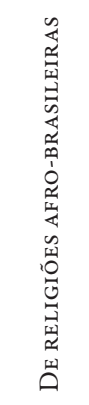 & 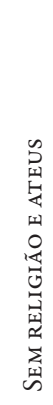 \\
\hline $\begin{array}{l}\text { Considera importante a opinião } \\
\text { dos líderes religiosos que fazem } \\
\text { campanha para políticos ligados } \\
\text { a igreja }\end{array}$ & $13,3 \%$ & $10,9 \%$ & $20,7 \%$ & $14,1 \%$ & $11,9 \%$ & $7,5 \%$ & $(*)$ \\
\hline $\begin{array}{l}\text { Já votou em candidatos recomen- } \\
\text { dados por sua igreja }\end{array}$ & $8,5 \%$ & $5,1 \%$ & $17,7 \%$ & $13,8 \%$ & $3,3 \%$ & $3,1 \%$ & $(*)$ \\
\hline $\begin{array}{l}\text { Apoia a ideia de que líderes re- } \\
\text { ligiosos devem se candidatar a } \\
\text { cargos políticos }\end{array}$ & $30,5 \%$ & $24,6 \%$ & $43,3 \%$ & $40,3 \%$ & $25,9 \%$ & $34,4 \%$ & $(*)$ \\
\hline $\begin{array}{l}\text { Concorda que candidatos ligados } \\
\text { à Igreja católica são melhores que } \\
\text { os demais }\end{array}$ & $9,0 \%$ & $10,4 \%$ & $8,4 \%$ & $6,0 \%$ & $6,4 \%$ & $7,6 \%$ & 6,2 \\
\hline $\begin{array}{l}\text { Concorda que candidatos ligados } \\
\text { a Igreja evangélica são melhores } \\
\text { que os demais }\end{array}$ & $9,1 \%$ & $5,4 \%$ & $20,1 \%$ & $14,4 \%$ & $6,3 \%$ & $2,7 \%$ & 5,5 \\
\hline Número de casos & 3758 & 2024 & 775 & 328 & 131 & 45 & 313 \\
\hline
\end{tabular}

${ }^{(*)}$ Não se aplica.

Fonte: Datafolha, pesquisa nacional realizada de 6 a 7 de junho de 2013. 
Cabe ressaltar, entretanto, que a maior presença da preocupação eleitoral no âmbito pentecostal não acarreta, necessariamente, maior obediência por parte dos fiéis. É amplamente conhecido o fato de que diversas igrejas pentecostais têm a atividade política como uma de suas principais frentes (Machado e Burity, 2014; Campos, 2006; Oro, 2006). Nas outras religiões, essa atuação, quando existe, é muito mais nuançada. O catolicismo pode até apoiar, mas não lança candidatos. $\mathrm{O}$ mesmo vale para as religiões afro-brasileiras e espírita. Por isso mesmo, apenas 5,1\% dos católicos dizem ter votado nos candidatos apoiados por sua igreja, taxa que chega aos $17,7 \%$ entre os pentecostais.

A propalada "fidelidade eleitoral" dos pentecostais, muitas vezes vendida a peso de ouro por suas lideranças nas barganhas político-partidárias, apesar de ser muito mais influente do que o observado para as demais religióes, atinge apenas uma minoria dentro de seu próprio universo. Segundo Ricardo Mariano, o poderio eleitoral dos pentecostais, "tão avidamente cobiçado por partidos e candidatos, e por isso tornado sua moeda de troca a cada pleito, embora não seja pequeno, costuma ser menor do que o por eles alardeado. Vendem gato por lebre” (1999, p. 235). A grande maioria dos fiéis pentecostais simplesmente não considera importante a opinião de suas lideranças na hora de votar.

Tal comportamento seletivo dos fiéis estende-se para além do plano político: "os crentes modernos reivindicam o seu 'direito de bricolagem'” e constroem seus próprios sistemas de crença, à revelia das orientações pregadas nas igrejas que frequentam (Hervieu-Léger, 2015, pp. 63-64). Antes, as religiões forçavam uma racionalização ética da vida, que precisava ser coerente com certos princípios. Hoje, filiar-se a uma religião não significa mais adotar todos os seus valores nem seguir todos os seus princípios. A "postura da maioria dos fiéis mudou: de seguidores leais, eles passaram a ser consumidores seletivos" (Bruce, 2016, p. 179). Assim como eles não compram para si todas as orientações religiosas apregoadas em suas igrejas, tampouco compram passivamente as orientações políticas.

Pode-se constatar também com esses dados que, apesar de ser pequena a parcela dos eleitores que reputam importante a opinião de líderes religiosos que fazem campanha para políticos ligados à igreja, é muito maior a quantidade daqueles que apoiariam a candidatura de líderes religiosos. Nesse quesito, os pentecostais aparecem novamente na liderança com 43,3\%. Como vimos, menos da metade desses eleitores disseram já ter votado nos candidatos recomendados por sua igreja. Ou seja, eles titubeiam em votar em um candidato desconhecido indicado pelas lideranças nas igrejas, mas não quando se trata de candidatura de lideranças religiosas. Essa diferença é acentuada entre os adeptos das religiões afro-brasileiras. Enquanto somente 3,1\% disseram já ter votado em candidatos recomendados por suas lideranças, 34,4\% afirmaram que votariam em seus líderes religiosos. 
Quando os líderes religiosos aceitam esse desafio e participam da disputa eleitoral, eles tendem a não entrar em partidos grandes, que demandam maior engajamento institucional. Trata-se mais de uma incompatibilidade "de ordem prática do que ideológica", pois "dificilmente o político teria condições de investir simultaneamente e com a intensidade que é requerida na instituição religiosa e no partido" (Steil, 2001, p. 83). Assim, os candidatos religiosos tendem a não se tornar "políticos profissionais" e costumam entrar em partidos pequenos, sem expressão, ou criar os seus próprios partidos. Nesses, a identidade religiosa não precisa competir com a identidade do partido.

Os pentecostais que afirmam que os candidatos ligados à Igreja evangélica são melhores que os demais perfazem 20,1\%, número pouco expressivo visto separadamente, mas que é o dobro dos 10,4\% de católicos que afirmam que os candidatos ligados à Igreja Católica são melhores que os demais. Os evangélicos não pentecostais, mais próximos da tradição, ficam a meio caminho com $14,4 \%$.

Tudo isso não é, ou pelo menos não deveria ser, motivo de alarde. Muito menos entre os cientistas sociais, alguns dos quais olham para essa cena política com um quarto de seu espaço tomado por evangélicos e saem gritando aos quatro ventos: “Dessecularização! Retorno do Sagrado! Revanche de Deus!”. Quem tem medo da bancada evangélica? Esses evangélicos na política não propõem um Estado religioso. Sua incursão na política até favorece a secularização ao contestar o monopólio católico na esfera pública (Mariz, 2000, p. 28). Isso porque, ao menos na modernidade ocidental, "a pretensão que a religião tem de reger a sociedade inteira e governar toda a vida do indivíduo foi se tornando ilegítima, mesmo aos olhos dos crentes mais convictos e mais fiéis" (Hervieu-Léger, 2015, p. 34). E isso não só porque as religiões e os fiéis mudaram, mas também porque o próprio avanço da racionalização do Estado o torna cada vez "menos acessível à eticização substantiva" (Weber, 1980, p. 247). Ou seja, mesmo que quisesse, nenhuma religião teria, nas atuais condições sociais, capacidade de alterar os fundamentos e os aportes que regem o funcionamento e a reprodução das instituições sociais modernas.

A sociedade moderna inteira não pode ser, portanto, neopentecostal, do candomblé ou da católica carismática. "Nem há de conformar-se em ter apenas uma única religião os que se fartam em usufruir do que cada uma delas pode oferecer para o seu interesse" (Prandi, 1996, p. 273). Em decorrência da ênfase individualista, dissolvente, "a capacidade de um impacto social mais amplo dessas crenças torna-se muito reduzida" (R. Santos, 2016, p. 177). A religião é hoje um bem de consumo, ela "não 
estrutura mais o espaço público nem é mais a matriz da lei” (Ferry e Gauchet, 2008, p. 23). Cada escolha do consumidor religioso não traz consequências reais para as instituições sociais, o poder político e os controles tecnológicos (Wilson, 1976, p. 96; Pierucci, 1997, p. 113). Às vezes esse consumo religioso não traz grandes consequências nem ao próprio indivíduo. Qualquer um pode mudar de religião sem que o mundo caia. Nos dias de hoje, a conversão não significa mais mudar radicalmente de vida (Prandi, 1996, pp. 260-262; Mariano, 1999, p. 232). Vale o lema: para um problema novo, uma religião nova. E a maior prova de que a religião saiu do lugar estruturante que ocupava antes é que vivemos em uma "sociedade ateia composta e governada por uma maioria de crentes” (Gauchet, 1985, p.3, tradução nossa).

Crentes esses que, seja no plano dos políticos, seja no do eleitorado, não encontram muitos temas comuns em torno dos quais possam formar identidades fortes $\mathrm{e}$ duradouras. A fluidez das crenças na modernidade impossibilita a formação dessas certezas partilhadas com base na religião (Hervieu-Léger, 2006, pp. 60-67). É por isso que os líderes religiosos têm hoje menos poder político do que já tiveram, como reconhece até mesmo Stark (1999, p. 252), um dos autores expoentes contrários à teoria da secularização. Ainda mais no Brasil de hoje, "cada vez mais secularizado, cada vez mais indiferente às instituições religiosas e aos poderes eclesiásticos tradicionais, cada vez mais radicalmente avesso às regras e imposições reguladoras da intimidade e do tempo de lazer e cada vez mais liberal no plano comportamental" (Mariano, 1999, p. 234).

Se mesmo quando eram mais poderosos os líderes religiosos foram incapazes de barrar diversas liberalizações no plano da moral e do comportamento, que dirá hoje. A Igreja católica no Brasil já combateu a presença da mulher no mercado de trabalho urbano, pois era "fora de casa”, ou seja, não relacionado com o serviço doméstico ou com a educação de crianças; o ensino de inglês na escola, porque preferia o tradicional francês; o aprendizado do violão e do acordeão, instrumentos de artistas boêmios; o cinema norte-americano, por sua falta de pudor; o uso de roupa masculina pela mulher, de maquiagem, de saia curta. Perdeu em todas essas questões e em outras mais, perdeu e "teve que aceitar, ajustou-se aos novos tempos" (Prandi, 2008, p. 168).

Continua não havendo, portanto, justificativa para o temor de que o crescimento do pentecostalismo no Brasil ameace a democracia (Mariano, 1999, p. 231). As igrejas pentecostais até detêm algum poder - rádios, emissoras de televisão, editoras etc. -, mas seu proselitismo nesses meios tem audiência específica e limitada, e seus produtos editoriais ou musicais "tampouco figuram no cenário nacional como atividades culturais relevantes" (Idem, pp. 231-234).

O engajamento dos evangélicos na esfera política limita-se a ser, como vimos, acima de tudo, reacionário. Sem muitos acordos para além daquilo que rejeitam 
no plano moral, eles se juntam principalmente para reagir a alguma proposta que consideram afrontosa, mais do que para propor alguma política moralmente edificante. Não só reacionários, portanto, mas também moralistas, posto que a união desses congressistas ocorre predominantemente em torno de pautas morais, e não em torno da elaboração de políticas públicas de cunho mais estrutural. Graças à sua presença, o linguajar religioso pode até reaparecer vez ou outra na esfera política, mas apenas como recurso simbólico. Para renovar os exemplos de Thomas Huxley (2009, p. 106), dificilmente veremos tramitar no Congresso algum projeto que proponha a pena de morte para feiticeiras, à moda bíblica (Êxodo, 22:18). Dificilmente algum parlamentar religioso proporá o uso da oração como solução para a falta de água nos grandes centros urbanos. Se houvesse um novo surto de peste, a atenção do Congresso, mesmo daquela ala religiosa, recairia sobre os esgotos, e não mais sobre as igrejas. Ou seja, hoje, são os religiosos que entram no jogo político, e não o jogo político que volta a se submeter às orientações religiosas (Prandi e Santos, 2015, pp. 375-376).

A bancada evangélica, que indubitavelmente marca uma nova presença na cena pública nacional, dá visibilidade às igrejas evangélicas, mas ainda não se mostrou capaz de orientar com eficácia e legitimidade nenhuma mudança de rota nos rumos do Brasil. O Congresso Nacional é o palco onde o segundo maior grupo religioso do país se exibe e busca reconhecimento, mas é também uma escola onde os recém-chegados representantes dessas igrejas aprendem com seus pares não religiosos, às vezes com muita dificuldade, as lições do jogo político-partidário, no qual a urna democrática se sobrepõe ao altar dos deuses, no qual os acordos e as negociações, e mesmo o duvidoso toma lá dá cá, são regidos por interesses e códigos alheios às palavras de livros sagrados, no qual o fazer da lei dispensa a revelação divina e a unção religiosa.

\section{Referências Bibliográficas}

BRUCE, Steve. (2016), "Secularização e a impotência da religião individualizada". Religião e Sociedade, 1 (36): 178-190.

Campos, Leonildo Silveira. (2006), "De políticas de Cristo: uma análise do comportamento político de protestantes históricos e pentecostais no Brasil”. In: BURITY, Joanildo \& MAChado, Maria das Dores Campos (orgs.). Os votos de Deus: evangélicos, política e eleições no Brasil. Recife, Massangana, pp. 29-90.

Diap - Departamento Intersindical de Assessoria Parlamentar. (2014), Radiografia do novo Congresso: legislatura 2015-2019. Brasília, Diap.

Durkheim, Émile. (2008), Da divisão do trabalho social. São Paulo, Martins Fontes. 
Ferry, Luc \& Gauchet, Marcel. (2008), Depois da religião. Rio de Janeiro, Difel.

FOLHA DE S. PAULO. (2015), "Parlamentares são mais liberais do que o eleitorado". Folha de S. Paulo, 13/10, p. A7.

Gauchet, Marcel. (1985), Le désenchantement du monde. Paris, Gallimard.

Hervieu-LÉger, Danièle. (2006), "In search of certainties: the paradoxes of religiosity in societies of high modernity". The Hedgehog Review: After Secularization, 1-2 (8): 59-68. (2015), O peregrino e o convertido. Petrópolis, Vozes.

HuXley, Thomas Henry. (2009), Escritos sobre ciência e religião. São Paulo, Editora da Unesp. IBGE. (2012), Censo demográfico 2010: características gerais da população, religião e pessoas com deficiência. Disponível em ftp://ftp.ibge.gov.br/Censos/Censo_Demografico_2010/Caracteristicas_Gerais_Religiao_Deficiencia/caracteristicas_religiao_deficiencia.pdf, consultado em 20/12/2015.

Machado, Maria das Dores Campos \& Burity, Joanildo. (2014), “A ascensão política dos pentecostais no Brasil na avaliação de líderes religiosos". Dados, 3 (57): 601-631.

Mariano, Ricardo. (1999), Neopentecostais: sociologia do novo pentecostalismo no Brasil. São Paulo, Loyola.

Mariz, Cecília Loreto. (2000), "Secularização e dessecularização: comentários a um texto de Peter Berger”. Religião e Sociedade, 1 (21): 25-39.

Oro, Ari Pedro. (2006), “A Igreja Universal e a política”. In: Burity, Joanildo \& MACHAdo, Maria das Dores Campos (orgs.). Os votos de Deus: evangélicos, politica e eleiçôes no Brasil. Recife, Massangana, pp. 119-148.

Pew Research Center. (2013), "Global views on morality: compare values across 40 countries”. Disponível em http://www.pewglobal.org/2014/04/15/global-morality/country/ brazil/, consultado em 30/11/2015.

Pierucci, Antônio Flávio. (1996a), "Representantes de Deus em Brasília: a bancada evangélica na Constituinte". In: Pierucci, Antônio Flávio \& Prandi, Reginaldo (orgs.). A realidade social das religiões no Brasil: religião, sociedade e politica. São Paulo, Hucitec, pp. 163-191. (1996b), “O povo visto do altar: democracia ou demofilia?". In: PIerucci, Antônio Flávio \& Prandi, Reginaldo (orgs.). A realidade social das religiões no Brasil: religião, sociedade e politica. São Paulo, Hucitec, pp. 35-58.

(1997), "Reencantamento e dessecularização: a propósito do autoengano em sociologia da religião”. Novos Estudos Cebrap, 49: 99-117.

\& Mariano, Ricardo. (1996), "O envolvimento pentecostal na eleição de Collor". In:__ \& PRANDI, Reginaldo (orgs.). A realidade social das religiões no Brasil: religião, sociedade e politica. São Paulo, Hucitec, pp. 193-210.

\& Prandi, Reginaldo. (1996), "Religiões e voto: a eleição presidencial de 1994". In: (orgs.). A realidade social das religiões no Brasil: religião, sociedade e politica. São Paulo, Hucitec, pp. 211-238. 
Prandi, Reginaldo. (1996), "Religião paga, conversão e serviço”. In: Pierucci, Antônio Flávio \& Prandi, Reginaldo (orgs.). A realidade social das religiões no Brasil: religião, sociedade e politica. São Paulo, Hucitec, pp. 257-273. . (2008). "Converter indivíduos, mudar culturas". Tempo Social, 2 (20): 155-172. \& Paulino, Mauro. (2015), "A política evangélica: em que temas ela é mais conservadora”. Folha de S. Paulo, 15/11, Ilustríssima, p. 3.

\& SAntos, Renan William. (2015), "Mudança religiosa na sociedade secularizada: o Brasil 50 anos após o Concílio Vaticano II”. Contemporânea, 2 (5): 351-379.

\& SouzA, André Ricardo de. (1996), "A carismática despolitização da Igreja católica”. In: Pierucci, Antônio Flávio e Prandi, Reginaldo (orgs.). A realidade social das religióes no Brasil. São Paulo, Hucitec, pp. 59-91.

Santos, Renan William dos. (2016), "Steve Bruce, um sociólogo em defesa da teoria da secularização”. Religião e Sociedade, 1 (36): 175-177.

SAntos, Wanderley Guilherme dos. (1979), Cidadania e justiça: a politica social na ordem brasileira. Rio de Janeiro, Campos.

Souza, André Ricardo de. (2011), "O empreendedorismo neopentecostal no Brasil”. Ciências Sociais e Religião, 15 (13): 13-34.

STARK, Rodney. (1999), “Secularization R. I. P.” Sociology of Religion, 3 (60): 249-273.

STEIL, Carlos Alberto. (2001), "Eleições, voto e instituição religiosa”. Debates do NER, 3 (2): 73-83.

Venturi, Gustavo. (2008), "Intolerância à diversidade sexual". Teoria e Debate, 78: 20-23.

Weber, Max. (1980), "Rejeições religiosas do mundo e suas direções". In: Tragtenberg, Maurício (org.). Textos selecionados: Max Weber. São Paulo, Abril Cultural, pp. 237-268.

Wilson, Bryan. (1976), Contemporary transformations of religion. Oxford, Clarendon. 


\section{Resumo}

Quem tem medo da bancada evangélica? Posições sobre moralidade e política no eleitorado brasileiro, no Congresso Nacional e na Frente Parlamentar Evangélica

Este artigo estuda a influência da filiação religiosa na opinião de eleitores e de seus representantes no Congresso Nacional, compara a opinião dos eleitores classificados segundo a religião declarada e analisa a opinião do conjunto dos congressistas e daqueles pertencentes à chamada bancada evangélica, formada por congressistas evangélicos não pentecostais e pentecostais. Também mostra que a religião influencia pouco a opinião de eleitores e congressistas nos temas de natureza econômica e estrutural e marca mais a opinião em temas do comportamento e moralidade, além de constatar que a bancada evangélica se move ora na direção de seus eleitores, ora na do conjunto dos congressistas, distinguindo-se como grupo sobretudo por sua preocupação com a moral sexual. Palavras-chave: Bancada evangélica; Congresso Nacional; Religião e política; Religião e moralidade; Religião e economia.

\section{Abstract}

Who is afraid of the Evangelical Bench? Positions of Brazilian voters, congressmen and the Evangelical Bench about morality and politics

This article studies the influence of religious affiliation on the opinion of voters and their representatives in Brazilian National Congress, compares the opinion of voters classified according to their religion and analyzes the opinion of congressmen and those belonging to the so-called Bancada Evangélica (Evangelical Bench), made up of non-Pentecostal Evangelical and Pentecostal Evangelical congressmen. It also shows that religion influences little the opinion of voters and congressmen in the themes of economic and structural nature, and influences more the opinion on issues of morality and behavior. Demonstrates that the Bancada Evangélica moves itself sometimes in the direction of their voters, some other times in the directions of the Congress as a whole, distinguishing itself as a group especially concerned with sexual morality.

Keywords: Evangelical Bench; National Congress; Religion and vote; Religion and morality; Religion and economics.

Texto recebido em 19/1/2016 e aprovado em 2/8/2016. DoI: 10.11606/0103-2070.ts.2017.1 10052 .

REGINALDO PRANDI é professor sênior do Departamento de Sociologia da Universidade de São Paulo (USP) e pesquisador 1A do CNPq. E-mail: rprandi@uol.com.br.

RENAN William dos santos é mestre pelo Programa de Pós-graduação em Sociologia da Universidade de São Paulo (USP), com o apoio da Fundação de Amparo à Pesquisa do Estado de São Paulo (Fapesp) e da Coordenação de Aperfeiçoamento de Pessoal de Nível Superior (Capes), processo n.2015/02123-8.E-mail: renan_william.santos@hotmail.com. 
